\title{
PENGARUH KUALITAS PELAYANAN DAN AKSESIBILITAS HALTE TERHADAP PENGAMBILAN KEPUTUSAN PENGGUNA JASA DI BUS TRANSJOGJA
}

\author{
Ery Masnain \\ Alumni Fakultas Ekonomi \\ Universitas Sarjanawiyata Tamansiswa \\ Email : erimasnain@gmail.com
}

\begin{abstract}
The purpose of this study was to find out how the decision-making process by consumers to use Transjogja buses from the aspect of service quality and accessibility of stops. This research is a type of quantitative research. The subjects in this study were people in Jetis village, Yogyakarta who used Transjogja buses. The method in this study is through questionnaires distributed to consumers who use Transjogja buses. The results of this study indicate that the influence of service quality and accessibility of shelters on consumer decision making to use Transjogja buses is very good. So that the good quality of service will increase consumers to use Transjogja buses and the services currently received will have a continuing impact in the future, so that in this case the quality service has a great influence on trust.
\end{abstract}

Keywords: service quality, accessibility of stops, consumer decisions.

\section{PENDAHULUAN}

Tingginya kemacetan dan kepadatan jalan menghiasi kota-kota besar di Indonesia. Begitu pula yang terjadi di kota Yogyakarta. Pernambahan penduduk dan tingginya mobilitas berperan aktif menyumbang kepadatan jalan di Yogyakarta. Kedua faktor diatas juga didukung oleh ketiadaan angkutan perkotaan yang sesuai. Angkotan kota yang berpotensi di Yogyakarta selama ini adalah bus kota, taksi, dan ojek online. Namun dari ketiga angkutan tersebut yang berpotensi memberikan dampak lebih besar terhadap pengurangan tingginya kemacetan dan kepadatan jalan adalah bus kota.

Bus kota merupakan angkutan transportasi massal perkotaan yang cukup populer di Yogyakarta. Namun dalam kenyataannya, bus kota yang selama ini melayani kebutuhan transportasi masyarakat kota di nilai tidak aman,terkesan kumuh dan tidak efisien, masih melekat pada angkutan bus kota. Pelayanan yang diberikan kepada pengguna juga jauh dari memuaskan. Hal tersebut mendorong pengguna bus kota beralih menggunakan kendaraan pribadi dan ojek online.

Pemerintah menyadari hal ini bahwa kebutuhan masyarakat akan angkutan massal perkotaan yang aman, bersih, murah dan nyaman harus terpenuhi. Selain itu pertambahan kendaraan pribadi dari tahun ke tahun semakin meningkat sehingga pemerintah Yogyakarta meluncurkan program massal berbasis perkotaan yang dinamakan Trans Jogja.

Kualitas pelayanan Trans Jogja menjadi sorotan karena mengalami penurunan dari tahun ke tahun. Pengguna mempertanyakan apakah masih layak Trans Jogja memiliki slogan "buy the service". kondisi fisik bus mengalami kerusakan dimanamana. Cat terkelupas, pintu tidak membuka/menutup secara otomatis, kursi rusak, dan 
simbol-simbol penting sudah tidak terpasang dengan baik telah menjadi pemandangan sehari-hari. Kondisi halte mengalami hal yang sama walaupun tidak separah seperti yang dialami bus.

Proses keputusan penggunaan barang atau jasa melalui lima tahapan menurut James Engel (1994: 31). Pengenalan kebutuhan, pencarian informasi, evaluasi alternatif, proses keputusan, dan hasil merupakan tahapan-tahapan yang harus dilalui oleh konsumen. Begitu pula halnya dengan proses pengambilan keputusan penggunaan Trans Jogja oleh masyarakat.

Aksesibilitas halte Trans Jogja erat kaitannya dengan pemilihan lokasi penempatan shelter tersebut. Pemilihan lokasi shelter sangat vital karena shelter merupakan alat distribusi pelayanan Trans Jogja. Semenjak beroperasi pada tahun 2008 penambahan shelter terus dilakukan oleh pemerintah. Jumlah shelter hingga tahun 2012 berjumlah 112 unit. Namun hanya 103 saja yang beroperasi dan 9 unit diantaranya merupakan shelter POS (Point of Sales). Shelter POS (Point of Sales) melayani masyarakat yang ingin membeli tiket dan smart card langganan Trans Jogja. Selain itu, Trans Jogja juga bekerja sama dengan bank dab minimarket untuk membuat dan memasarkan smart card Trans Jogja.

Jumlah shelter Trans Jogja yang berjumlah 112 buah belum cukup dalam mengakomodir kebutuhan masyrakat. Hal ini kerap menjadi keluhan masyarakat khususnya bagi pengguna dari luarr wilayah administratif Kota Yogyakarta. Selain itu sebaran shelter kurang menjadi perhatian instansi terkait, penempatan shelter kurang merata di luar wilayah administratif Kota Yogyakarta.

\section{TINJAUAN PUSTAKA DAN PENGEMBANGAN HIPOTESIS Keputusan Pembelian}

Kepuasan pelanggan merupakan elemen produk dalam pemasaran modern. Persaingan dalam pemasaran dapat dimenangkan apabila perusahaan mampu menciptakan dan mempertahankan pelanggan. Cara yang harus dilakukan perusahaan untuk mempertahankan pelanggan adalah dengan cara memahami prilaku konsumen sasaran secara komprehensif, pemahaman tersebut digunakan untuk merancang, mengkomunikasikan, dan menyampaikan program pemasaran secara lebih efektif dibandingkan para pesaing.

\section{Kualitas Pelayanan}

Pelayanan adalah suatu sikap atau cara dalam melayani pelanggan supaya pelanggan mendapatkan kepuasan yang meliputi kecepatan, ketepatan, keramahan dan kenyamanan. Pelayanan pelanggan merupakan elemen lain dari strategi produk, tawaran perusahaan kepada pasar biasanya meliputi beberapa jasa, yang dapat menjadi bagian yang besar atau kecil dari keseluruhan tawaran. Perusahaan sebaiknya mendesain produk dan jasa pendukungnya untuk memenuhi keinginan pelanggan yang menjadi sasaran pasarnya secara menguntungkan

\section{Aksesibilitas Halte}

Aksesibilitas merupakan suatu ukuran kenyaman atau kemudahan pencapaian lokasi dan hubungannya satu sama lain, mudah atau sulitya lokasi tersebut dicapai melalui transportasi. 


\section{METODE PENELITIAN}

Objek dalam penelitian ini adalah variabel kuaitas pelayanan dan aksesibilitas halte yang berpengaruh terhadap keputusan pengguna jasa menggunakan bus transjogja. Adapun teknik yang digunakan penulis dalam penelitian ini yang menggunakan data primer melalui menyebarkan kuesioner ke responden yang telah menggunakan bus transjojga. Metode pengumpulan data yang digunakan dalam penelitian ini adalah Kuantitatif yang akan menguji : uji validitas, uji reliabilitas, uji normalitas data, uji heterokedastisitas, uji multikolinieritas, uji f, uji t, uji $\mathrm{r}^{2}$.

\section{HASIL DAN PEMBAHASAN}

Pengaruh secara parsial antara pelayanan terhadap keputusan penggunaan sebesar 1.382 dengan sign. $0,70<\alpha=0,170$. Nilai sign. yang lebih kecil $\alpha=0,05$, menunjukkan ditolaknya hipotesis yang menyatakan Kualitas Pelayanan berpengaruh negatif terhadap Pengambilan Keputusan. Artinya Kualitas Pelayanan berpengaruh negatif terhadap Pengambilan Keputusan. Pengaruh secara parsial antara aksesibilitas halte terhadap keputusan penggunaan sebesar 2.483 dengan sign. $0,70<\alpha=0,15$. Nilai sign. yang lebih kecil $\alpha=0,05$, menunjukkan diterimanya hipotesis yang menyatakan Aksesibilitas Halte positif terhadap Pengambilan Keputusan. Artinya aksesibilitas halte positif terhadap Pengambilan Keputusan. Pengaruh secara parsial antara variabel kepercayaan terhadap keputusan penggunaan sebesar 0,723 dengan sign. $0,70<\alpha=0,472$. Nilai sign. yang lebih kecil $\alpha=0,05$, menunjukkan ditolaknya hipotesis yang menyatakan kepercayaan berpengaruh negatif terhadap Pengambilan Keputusan. Artinya kepercayaan berpengaruh negatif terhadap Pengambilan Keputusan. Pengaruh secara parsial antara variabel kehandalan terhadap keputusan penggunaan sebesar 1,581 dengan sign. $0,70<\alpha=0,117$. Nilai sign. yang lebih kecil $\alpha$ $=0,05$, menunjukkan ditolaknya hipotesis yang menyatakan Kehandalan berpengaruh negatif terhadap Pengambilan Keputusan. Artinya Kehandalan berpengaruh negatif terhadap Pengambilan Keputusan. Pengaruh secara parsial antara variabel jaminan terhadap keputusan penggunaan sebesar 1.331dengan sign. $0,70<\alpha=0,187$. Nilai sign. yang lebih kecil $\alpha=0,05$, menunjukkan ditolaknya hipotesis yang menyatakan Jaminan berpengaruh negatif terhadap Pengambilan Keputusan. Artinya Jaminan berpengaruh negatif terhadap Pengambilan Keputusan.

Tabel 1 Uji Hipotesis Coefficients $^{\mathrm{a}}$

\begin{tabular}{|c|c|c|c|c|c|c|}
\hline & \multirow[b]{2}{*}{ Model } & \multicolumn{2}{|c|}{ Unstandardized Coefficients } & \multirow{2}{*}{$\begin{array}{c}\text { Standardized } \\
\text { Coefficients } \\
\text { Beta }\end{array}$} & \multirow[b]{2}{*}{$\mathrm{t}$} & \multirow[b]{2}{*}{ Sig. } \\
\hline & & B & Std. Error & & & \\
\hline \multirow[t]{6}{*}{1} & (Constant) & 3.459 & 1.890 & & 1.830 & .070 \\
\hline & $\begin{array}{l}\text { Kualitas } \\
\text { Pelayanan }\end{array}$ & .160 & .116 & .139 & 1.382 & .170 \\
\hline & $\begin{array}{c}\text { Aksesibilitas } \\
\text { Halte }\end{array}$ & .367 & .148 & .273 & 2.483 & .015 \\
\hline & Kepercayaan & .174 & .241 & .080 & .723 & .472 \\
\hline & Kehandalan & .250 & .158 & .176 & 1.581 & .117 \\
\hline & Jaminan & .252 & 189 & .126 & 1.331 & 187 \\
\hline
\end{tabular}

a. Dependent Variable: $Y$ 


\section{PENUTUP}

Penelitian ini bertujuan untuk menguji pengaruh kualitas pelayanan dan aksesibilitas halte terhadap pengambilan keputusan pengguna jasa di bus Transjogja. Hasil temuan menunjukan sebagai berikut: Kualitas Pelayanan berpengaruh negatif terhadap Pengambilan Keputusan. Aksesibilitas halte positif terhadap Pengambilan Keputusan. Kepercayaan berpengaruh negatif terhadap Pengambilan Keputusan. Kehandalan berpengaruh negatif terhadap Pengambilan Keputusan. Jaminan berpengaruh negatif terhadap Pengambilan Keputusan.

\section{DAFTAR PUSTAKA}

Asih Purwanto (2008) Pengaruh Kualitas Produk, Promosi, dan Desain terhadap Keputusan Pembelian Sepeda Motor Yamaha Mio pada masyarakat di wilayah Surakarta https://elib.unikom.ac.id

Basu Swastha dan Irawan, 2005, Asas-asas Marketing, Liberty, Yogyakarta

Basu Swastha, 2001. Manajemen Pemasaran Modern. Yogyakarta

Basu Swastha dan Handoko, 2000. Manajemen Pemasaran Analisis Prilaku Konsumen, Edisi 1, Yogyakarta: Liberty

Basu Swastha, Ibnu Sukotjo. 2010. Pengantar Bisnis. Liberty. Yogyakarta

Erika Putri Pratiwi. (2010). Analisis Pengaruh Kualitas Produk, dan Harga terhadap Keputusan Pembelian Konsumen Sepeda Motor Yamaha Jupiter-Z. (Pada Dealer Yamaha Flag Ship Shop Pemuda Semarang e-theses.uin-malang

Ghozali, Imam. 2011. Analisis Multivariat dengan Program SPSS. Edisi ke-3. Badan penerbit UNDIP. Semarang. Jurnal Ekonomi Manajemen

Ghozali, Imam. 2012. Aplikasi Analisis Multivariat dengan Program IBM SPSS 20. Semarang : Badan Penerbit - Unversitas Diponegoro

Kotler, P. dan G Amstrong. 2004, Prinsip-prinsip Marketing, edisi ketujuh, penerbit sakemba empat, jakarta

Kotler, Philip. 2000. Manajemen Pemasaran. Edisi Milienium. Jakarta : PT. Indeks Kelompok Gramedia

Kotler dan Armstrong. 2012. Manajemen Pemasaran. Jilid I. Edisi ke 13. Jakarta : Erlangga

Kotler dan Armstrong. 2008. Prinsip-prinsip Pemasaran. Jilid I dan 2. Edisi 12. Jakarta

Salim Maghfur. (2017). Analisis Pengaruh Kualitas Produk, Harga dan Promosi Terhadap Keputusan Pembelian Shampo Pantene di Kota Wates. Yogyakarta

Sugiyono. 2012. Metode Penelitian Kuantitatif dan Kualitaif dan $R \& D$. Bandung : Alfabeta

Sugiyono. 2013. Statistik Untuk Penelitian. Bandung. Alfabeta 
Tjiptono. 2008. Strategi Pemasaran, Edisi ke 3. Andi, Yogyakarta

Tjiptono. 2008. Service Management Layanan Prima. Edisi Ke 2. Penerbit CV. Andi Offset. Yogyakarta

Dedek K. Gultom, Paham Gintin, Beby KF Sembiring 1 Alumni Magister Ilmu Manajemen SPs USU

Fadhilah Ismi Bazai, Wuryaningsih Dwi Sayekti, Dyah Aring Hepiana Lestari 2017.

Penerapan Strategi Pemasaran Dan Aksesibilitas Rumah Tangga Terhadap Bihun

Tapioka di Kota Metro 